Minter, J. W., ISD

McDevitt, R. F., ISD

Merlo, M. A., is

Ekis, A., ISD

Holland, W., IMD

Tatro, E. R., EMD

\section{Student Members}

Deacon, J. E.

Schwartzman, A. M.

\section{Versatile alloy Dentillium is boon to dentists, patients}

In October 1972 Codesco Inc.-a Philadelphia-based dental supply and laboratory company-began selling Dentillium, an iron-chromium alloy developed as a substitute for costly dental gold. The case for the new material rests solidly on the following claims, as noted in Business Week for July 14, 1973:

1) Cheaper, costing dental labs $\$ 10$ to $\$ 30$ per oz, vs $\$ 120$ to $\$ 150$ per oz for dental gold, a gold alloy containing platinum, palladium, silver, and some base metal whose price has been rising along with that of gold.

2) Stronger, permitting longer bridge spans.

3) More resistant to stains because of denser surface.

4) Lighter by about one-half, which reduces both the weight and the cost of the metal needed.

5) Less heat-conductive, producing fewer painful twinges when a cold martini follows a hot hors d'oeuvre.

\section{Filling a need}

Dentillium is a form of Illium, a corrosion-resistant alloy developed and manufactured by Stainless Foundry \& Engineering, Inc. of Milwaukee. Illium alloys first replaced platinum in containers used to measure the heat content in coal as it burned and in other versions were used in the manufacture of fertilizer, but the versatile alloys suggested themselves for dental purposes and when the Brookdale Center of New York University-which had been conducting research on nonprecious dental alloys since 1961-approached Stainless, the company was ready with Dentillium. Brookdale chose it over 550 other prospects and is currently testing the alloy in the mouths of 500 patients.

Stainless Foundry \& Engineering has specialized in corrosion resistant alloy development since it was founded in 1946. John McBroom, co-founder and currently president of Stainless, is a long-time member of The Metallurgical Society. His contributions to the annual Electric Furnace Conference extend back over 27 years and include both active committee participation and the chairmanship of the Conference in 1967. William J. Parana, Executive Vice President of Stainless Foundry \& Engineering, Inc., is also a TMS member. ing or application of the sciences to any branch of the mineral industry, and have held positions in responsible charge of engineering or technical work for three years.

Associate Members must be engaged in work relating to AIME's fields of interest with professional stature in other than engineering or science. Associate Members must have a college degree plus four years in a responsible position or a minimum of six years in a responsible position without a college degree.

Junior Members must be under $\mathbf{3 0}$ years of age and hold a subordinate engineering position. They may remain Junior Members until age 33, at which time they are automatically transferred to the grade of Associate Member.

Student Members are students in good standing at a degree-granting school approved by the AIME Board of Directors who have been nominated by one instructor. They will be transferred automatically to Junior Member upon graduation.

Both ASM and AIME have several classes of dues-exempt honorary membership.

\section{Dues Structure}

1973 Dues: SME-AIME and TMS-AIME

\begin{tabular}{|c|c|c|}
\hline Grade & $\begin{array}{c}\text { Annual } \\
\text { Dues }\end{array}$ & $\begin{array}{c}\text { Entrance } \\
\text { Fee }\end{array}$ \\
\hline \multirow[t]{2}{*}{$\begin{array}{l}\text { Member } \\
\text { Associate Member } \\
\text { Junior Member } \\
\text { Student Member } \\
\text { Joint ASM/TMS Student } \\
\text { Member }\end{array}$} & $\begin{array}{r}\$ 30.00 \\
30.00 \\
18.00 \\
4.50\end{array}$ & $\begin{array}{l}\$ 20.00 \\
20.00 \\
\text { None } \\
\text { None }\end{array}$ \\
\hline & 5.00 & None \\
\hline
\end{tabular}

1973 Dues: SPE-AIME

$\begin{array}{lrr}\text { Member } & \$ 20.00 & \$ 20.00 \\ \text { Associate Member } & 20.00 & 20.00 \\ \text { Junior Member } & 12.00 & \text { None } \\ \text { Student Member } & 4.50 & \text { None }\end{array}$

Student Member

1973 Dues: ASM

Individual Member $\$ 15.00$

Sustaining Member (minimum) 30.00

Sustaining Member

Student Member
Joint ASMITMS Student

Joint ASMI

5.00

5.00

Member

West. Hemisphere

West. Hemisphere

tional Chapter(s)

18.00

None

5.00

7.50

None

Geographical Distribution of Membership

\begin{tabular}{lcc} 
Region & $\begin{array}{c}\text { Percentage } \\
\text { ASM } \\
\text { Membership }\end{array}$ & $\begin{array}{c}\text { Percentage } \\
\text { AlME } \\
\text { Membership }\end{array}$ \\
$\begin{array}{lcc}\text { Northeast } \\
\text { North Central }\end{array}$ & $20 \%$ & \\
$\begin{array}{l}\text { Northwest } \\
\text { Southwest }\end{array}$ & 37 & $18 \%$ \\
$\begin{array}{l}\text { South Central } \\
\text { Southeast }\end{array}$ & 10 & 17 \\
Foreign & 9 & 17 \\
& 8 & 18 \\
& 10 & 9 \\
\hline
\end{tabular}

\section{Financial Summary}

The AIME Corporation is the legal entity through which all its subsidiary units exist and is the owner of all AIME assets now totaling some $\$ 5,900,000$. The 1973 budgeted revenue for AIME is approximately $\$ 2,900,000$. which is made up largely of revenue from member dues and fees, publications and meetings, the balance deriving from income on investments and AIME Endowment and Custodian Funds. Member dues constitute approximately 36 percent of total revenue. Budgeted expenses for 1973 total approximately $\$ 2,800,000$ for operation of the three Constituent Societies and their ongoing programs of member services, and the AIME Corporate Headquarters.

ASM has assets of approximately $\$ 4,640,000$. The ASM financial plan for 1973 calls for an operating budget of $\$ 4,138,000$. The principal income sources are periodical publications and reference publications which contribute up to 70 percent of the total income; membership dues, after allocation to the Chapters, will produce approximately 8.5 percent of the total income in 1973.

\section{Merger Study Considerations}

A great many persons engaged in metallurgy and materials science are members of both ASM and AIME and are active in the administration and technical activities of both societies. Two of the primary advantages of a merger would be the elimination of duplicate membership and the consolidation of administration, committees, and technical activities of the two organizations. Other advantages would accrue from the economics of operation because of the increase in size of the combined organization. Major considerations in the merger study will therefore include an examination of the membership of the two societies, what the membership needs are, how these needs are now fulfilled, and how a merged or new society could be structured to provide optimum services and opportunities for participation.

Practical matters that will also be considered will include the problems of combining the two corporations. Attorneys have advised of several ways that the two corporations can be merged from a legal standpoint. However, complex problems will exist in any combined structure, such as the handling of property and assets, differing membership requirements and dues structure, corporate headquarters financing and operation, and the election of officers and a governing board for representation of all membership groups in both societies.

Progress of the merger study will be reported to the governing boards and the memberships of both AIME and ASM as developments occur. 